\title{
THE STUDENTS' MATHEMATICAL PROBLEM-SOLVING ABILITIES, SELF-REGULATED LEARNING, AND VBA MICROSOFT WORD IN NEW NORMAL: A DEVELOPMENT OF TEACHING MATERIALS
}

\author{
Citra Megiana Pertiwi, Euis Eti Rohaeti*, Wahyu Hidayat \\ Institut Keguruan dan Ilmu Pendidikan Siliwangi, Indonesia
}

\begin{tabular}{l} 
Article Info \\
\hline Article history: \\
Received Sep 30, 2020 \\
Revised Oct 15, 2020 \\
Accepted Nov 12, 2020 \\
\hline Keywords: \\
Mathematical Problem-Solving, \\
Self-Regulated Learning, \\
Virtual Basic Aplication, \\
Microsoft Word, \\
Teaching Material
\end{tabular}

Article Info

rticle history:

Received Sep 30, 2020

Revised Oct 15, 2020

Keywords

Mathematical Problem-Solving,

Virtual Basic Aplication,

Teaching Material

\begin{abstract}
The new normal period makes ICT-based education the spearhead of the implementation of learning. This becomes an obstacle and a challenge for students, especially in the mathematical problem-solving ability (MPSA), which is very important for students because it is a prior mathematical ability and is included in HOTS. Self-regulated learning in mathematics (SRL) also has a significant role in adapting to learning in the new normal and influences students' mathematical learning outcomes. However, the facts on the ground show that these two abilities are still low. To solve this problem, the researchers developed VBA Microsoft Word-based teaching materials on the relevant polyhedron materials for use so that learning would be more optimal. The method used in this research is an experimental method with a pretestposttest control group design. The population is all the students in Cimahi City, while the sample is two classes randomly selected. This study indicates that VBA Microsoft Word-based teaching materials are appropriate to be applied in the new normal period, as indicated by the results of the achievement and improvement of MPSA and SRL of students is better than ordinary learning. There is an association between MPSA and SRL and positive response even though they still have difficulty making mathematical models on MPSA questions. Students are more enthusiastic in learning and don't get bored quickly; in line with the challenges of the new normal, the industrial revolution 4.0, and the learning curriculum, learning is more structured, interactive, effective, and efficient.
\end{abstract}

Copyright $($ C) 2021 IKIP Siliwangi. All rights reserved.

\section{Corresponding Author:}

Euis Eti Rohaeti,

Department of Mathematics Education,

Institut Keguruan dan Ilmu Pendidikan Siliwangi,

Jl. Terusan Jenderal Sudirman, Cimahi, West Java 40526, Indonesia.

Email: e2rht@ikipsiliwangi.ac.id

\section{How to Cite:}

Pertiwi, C. M., Rohaeti, E. E., \& Hidayat, W. (2021). The students' mathematical problem-solving abilities, self-regulated learning, and VBA Microsoft Word in new normal: A development of teaching materials. Infinity, 10(1), 17-30.

\section{INTRODUCTION}

The new normal period was created from adaptation to the Covid-19 pandemic, making social distancing and online activities a new lifestyle, including in the field of education. In the new normal era, ICT-based education has become the spearhead of the 
implementation of learning both directly and at a distance. This becomes an obstacle and a challenge for students in participating in learning, especially aspects that are important to student life such as problem-solving abilities. Mathematical problem-solving ability (MPSA) according to Harisman, Noto and Hidayat (2020) is the ability of students to understand problems, plan strategies, and implement problem-solving plans. Hendriana, Rohaeti and Hidayat (2017) state that solving math problems is a basic mathematical ability that must be embedded in high school students. MPSA is very important for students to be able to solve problems in mathematics, learning, and student life at large. This is also because problem-solving abilities are classified as high-order thinking skills. However, the importance of MPSA is not in line with the facts in the field which still show that the mathematical problem solving abilities of students are still low (Harisman et al., 2020; Hutajulu, Wijaya, \& Hidayat, 2019; Kusmaryono, Suyitno, Dwijanto, \& Dwidayati, 2018; Latifah \& Widjajanti, 2017; Maharani, Kholid, Pradana, \& Nusantara, 2019; Maulidia, Johar, \& Andariah, 2019; Putra, Thahiram, Ganiati, \& Nuryana, 2018).

In addition to problem-solving skills, another important ability for students is the ability to learn independently. Self-regulated Learning is a learning process where students can take the initiative, with or without the help of teachers/friends/other people, to diagnose needs, formulate goals, identify sources, select and implement strategies, and evaluate learning outcomes that suits him (Adam et al., 2017; Gabriel, Buckley, \& Barthakur, 2020; Guo, Lau, \& Wei, 2019; Guo \& Wei, 2019; Losenno et al., 2020; Samo, 2016). Selfregulated learning is an attitude with the characteristics of having the initiative, diagnosis, setting goals, monitoring, organizing and controlling, searching for and utilizing relevant sources, selecting and implementing strategies, and evaluating processes. The student learning outcomes, including having a self-concept and viewing adversity as a challenge (Cárdenas-Robledo \& Peña-Ayala, 2019; Peters-Burton, Cleary, \& Kitsantas, 2018).

Self-regulated learning is the ability of students to carry out the learning process without depending on others. ICT-based learning in the new normal period makes learning independence have a big role in determining student understanding of learning. This is in line with the statement of Kamal (2015) which explains that the self-regulated of student learning in mathematics is one aspect that contributes to the success and achievement of students in learning mathematics. Self-regulated learning is one of the factors that affect students' mathematics learning outcomes that originate within students. Self-regulated learning is predicted to play a role in the achievement of students' mathematical learning outcomes (Adam et al., 2017; Cárdenas-Robledo \& Peña-Ayala, 2019; Gabriel et al., 2020; Guo et al., 2019; Guo \& Wei, 2019; Losenno et al., 2020; Peters-Burton et al., 2018; Samo, 2016). However, the self-regulated of students' mathematics learning is not easy to be maximally improved because of the many factors that affect students' desire to learn (Krisnawati, Rohaeti, \& Maya, 2018; Rahmawati, Rohaeti, \& Yuliani, 2018).

To overcome this problem, one solution that can be taken is to return to the basics of learning itself, namely regarding the teaching materials used. Based on the observations made, the teaching materials used during learning during the new normal period still do not support adequate ICT-based learning. So we need ICT-based teaching materials that can improve MPSA and student SRL. Based on these problems and needs, researchers created and developed Visual Basic Application (VBA) for Microsoft Word teaching materials which are expected to be a solution. This teaching material is very relevant for use in online learning which is very dependent on the use of ICT so that online learning will be carried out more optimally (Wahyudi, Ambarwati, \& Indarini, 2019). This teaching material is a learning tool that contains learning materials, student worksheets, and evaluation tools using VBA for Microsoft Word to improve students' MPSA, especially in polyhedron materials. This teaching material can give an interactive, effective, efficient, modifiable impression, 
can be adjusted to the desired theme, and provide audio and visual stimulation. Besides, it is hoped that it can improve MPSA, especially the polyhedron material and increase students' SRL during learning during the new normal period.

The objectives and problem formulations in this study are: (1) How is the implementation of VBA Microsoft Word teaching materials for junior high school students during the New Normal period? (2) Can teaching materials based on VBA Microsoft Word improve the mathematical problem-solving abilities of junior high school students ? (3) Can teaching materials based on VBA Microsoft Word improve self-regulated learning for junior high school students?

\section{METHOD}

The method used in this study is the experimental method to shapes of pretest-postest control group design. The experimental class received learning with teaching materials based on Visual Basic for Microsoft Word Applications, while the control class used ordinary learning (OL), in which both classes learned online. The population in this study were all students of State Junior High School in Cimahi City, while the sample was two classes randomly selected. The instrument used in this study was a test item in the form of a description of the MPSA as many as 6 questions and a scale of SRL as many as 28 statements, as well as the giving of 38 student response questionnaires and interview guidelines for a preliminary study of potential problem analysis.

Examples of instruments used as references in measuring mathematical problemsolving abilities, self-regulated learning and closed questionnaires about VBA teaching materials based on Microsoft Word are presented in Figure 1, Figure 2, and Figure 3, respectively.

Mrs. Ani is a businesswoman making camping tents. Where the tent is a combination of the cube and the prism of the isosceles triangle. When making a tent, it requires a capital of Rp $15.000 / \mathrm{m}^{2}$ for the fabric and Rp $10.000 / \mathrm{m}$ for the support poles. The cost of making 1 tent will be calculated.

a) Write down the known and asked elements in the above situation and draw the tent illustration into the mathematical model! Along with determining the sizes of the tent

b) Compile a mathematical model to calculate the cost of making 1 tent. Write down the concepts contained in the model

c) Complete the model and write down the concepts used in each completion step

d) Check the correctness of the solution obtained

Figure 1. MPSA Instrument

\begin{tabular}{l|l|l|l|l|l|l|} 
No & Take the initiative to learn with or without the help of others & QO & O & ST & S & QS \\
\hline 1. & I complete my study using VBA teaching materials of my own accord & & & & & \\
\hline 2. & I studied flat-sided building materials from various sources & & & & & \\
\hline 3. & I am waiting for the explanation of the material by the teacher & & & & & \\
\hline 4. & $\begin{array}{l}\text { I try to solve problem-solving problems myself first before asking my } \\
\text { teacher or friends }\end{array}$ & & & \\
\hline 5. & I work on assignments when invited by a friend & & & & \\
\hline Note: & QO: quiet often \\
O : often & ST: some times QS: quiet seldom \\
\end{tabular}

Figure 2. SRL Scale 


\begin{tabular}{|c|c|c|c|c|}
\hline Statement Topic & QO & $\mathbf{O}$ & ST & $\mathbf{S}$ \\
\hline $\begin{array}{l}\text { I feel comfortable learning flat-sided building materials using VBA for Microsoft } \\
\text { Word teaching materials }\end{array}$ & & & & \\
\hline I hesitate to represent my friends to run VBA for Microsoft Word teaching materials & & & & \\
\hline $\begin{array}{l}\text { I dare to argue when the material in the VBA for Microsoft Word teaching materials is } \\
\text { wrong }\end{array}$ & & & & \\
\hline $\begin{array}{l}\text { I lost my enthusiasm for learning flat-sided building materials when learning to } \\
\text { use VBA for Microsoft Word teaching materials }\end{array}$ & & & & \\
\hline $\begin{array}{l}\text { I am challenged to complete all the learning stages in the VBA for Microsoft Word } \\
\text { teaching materials }\end{array}$ & & & & \\
\hline 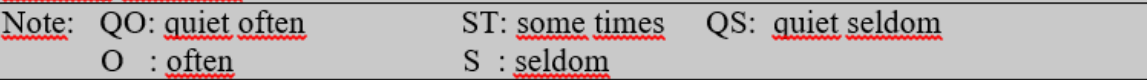 & & & & \\
\hline
\end{tabular}

Figure 3. Response Questionnaire of VBA Microsoft Word

\section{RESULTS AND DISCUSSION}

\subsection{Results}

The low MPSA and SRL of students during learning during the new normal period is a problem that must be resolved immediately because there is no clarity on how long the Covid-19 pandemic will end. Therefore, ICT-based teaching materials are needed that can be used in face-to-face, online, and offline learning conditions. Given that solving daily problems requires mathematical problem-solving skills and soft skills for students to learn independence because during the new normal period students are required to learn more independently. In addition, teaching materials are needed in accordance with the thinking stage of junior high school students, most of which are still at the concrete stage while the nature of mathematics is abstract.

From the interviews with junior high school teachers who experienced learning during the normal period, it is just known as follows: (1) Learning in the new normal period gives teachers and students the choice of face-to-face, offline, and online learning. However, to maintain safety, teachers choose online learning. However, learning is not optimal because there is no adequate digital-based teaching material; (2) Online learning makes students tired quickly, so that the implementation of learning is not optimal. It takes teaching materials that can make students able to self-regulated learning according to the time that students are interested in; (3) During the new normal learning, students are confused about mastering MPSA. Therefore, systematic teaching materials are needed following the meaning of mathematics itself; and (4) Following the teacher's experience, mathematics material, which is considered difficult is the geometry materials. This is the teacher's concern in delivering the material because even face-to-face learning is the most difficult. So that it becomes a challenge in itself when learning online.

\subsubsection{Instructional Material Design Based on Visual Basic Application for Microsoft Word}

Based on teaching materials VBA for Microsoft Word have some stuffing content. Figure 4 is an initial display of VBA Microsoft Word -based teaching materials where there is a title, group name, member name, time. In addition, there is a button to turn on the audio, how many back sounds can be adjusted. 


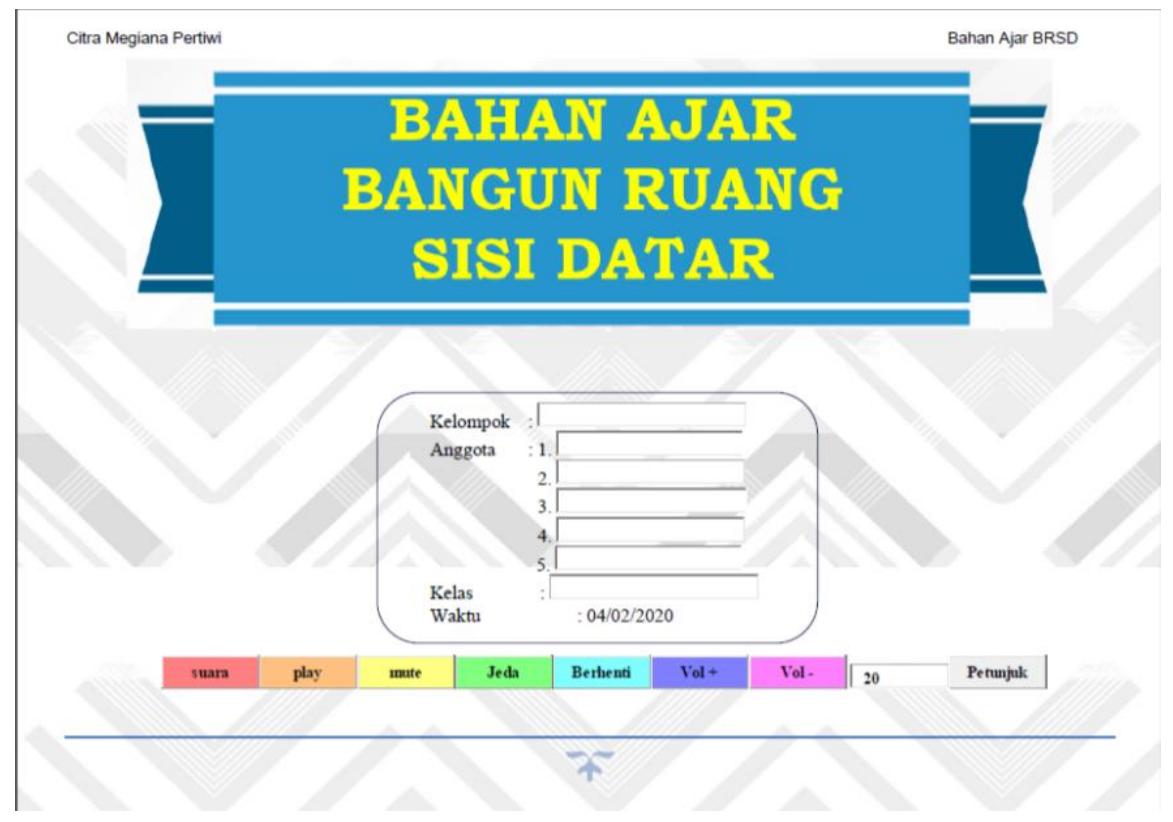

Figure 4. Display a cover of teaching material

Figure 5 is a sample of teaching material content based on VBA Microsoft Word where there are conceptual findings on the volume and surface area of the cube. In addition, teaching materials contains material from recognizing prisms and pyramids, making characteristics and definitions of prisms and pyramids, distinguishing the sizes of cubes and blocks, proving the volume of cubes and blocks, comparing the volume of prisms and pyramids, finding the formula for the surface area of prisms and pyramids, until as in Figure 6 , it is an evaluation tool that contains MPSA questions with different level of pain indexes.
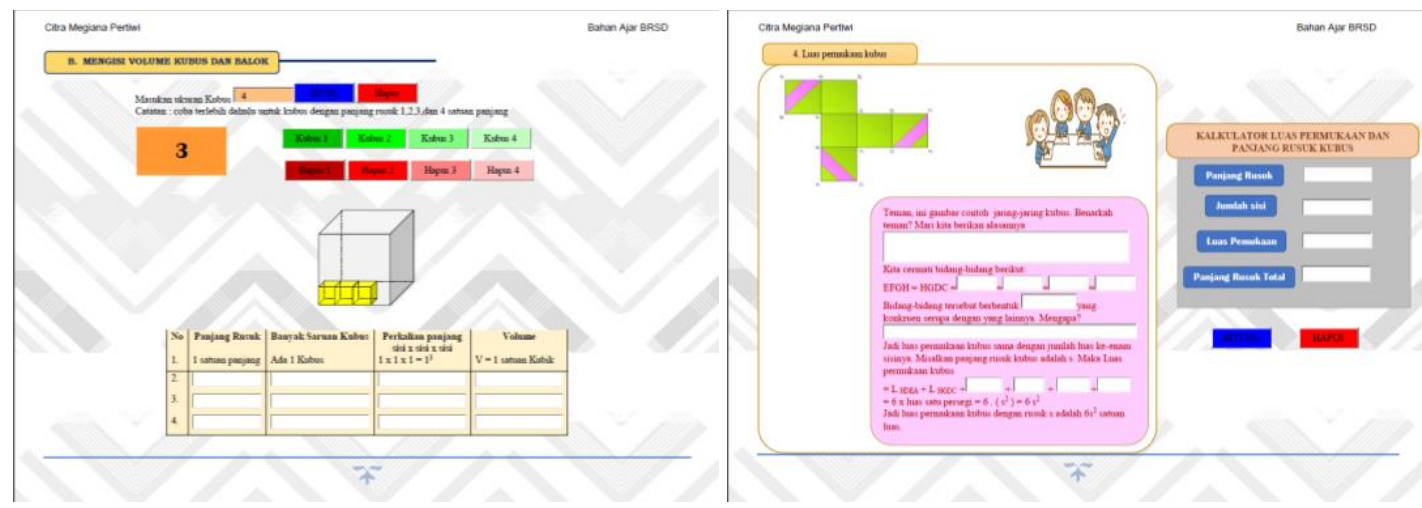

Figure 5. Concept discovery content samples 


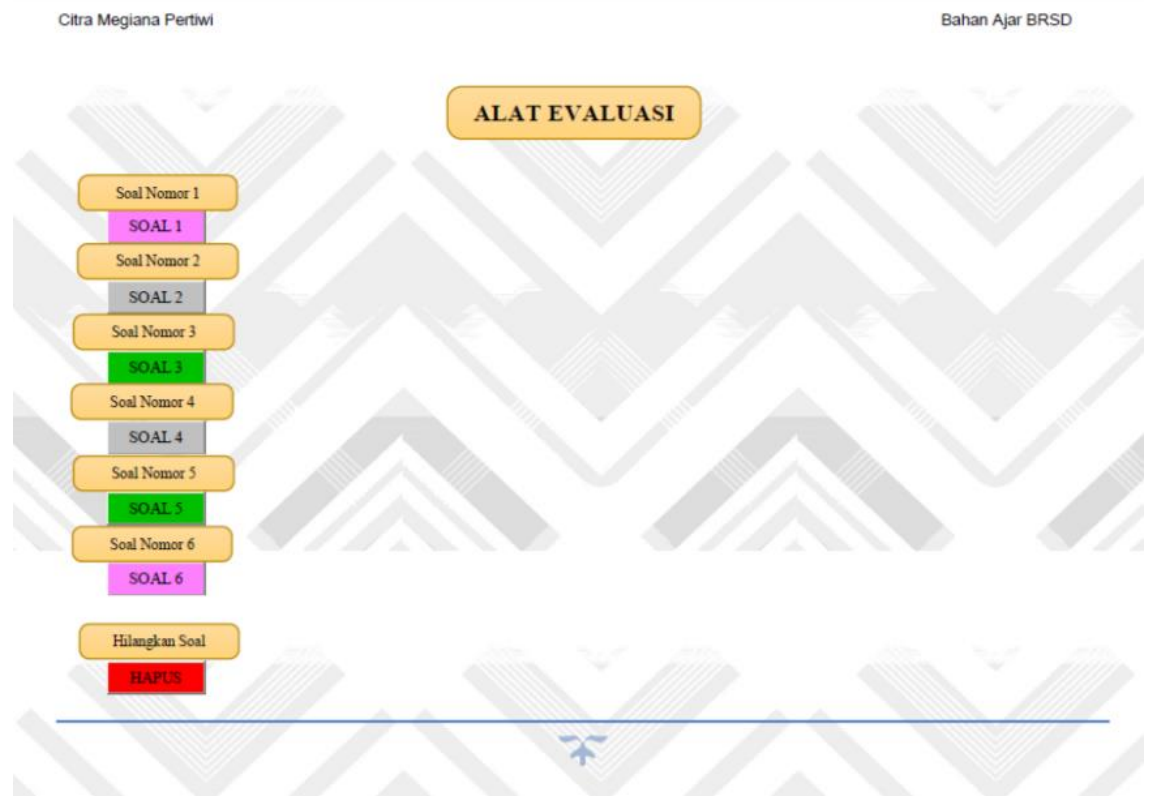

Figure 6. Evaluation tool

\subsubsection{Results of Mathematical Problem-Solving Ability, Self-Regulated Learning, as well as the Questionnaire Responses Students}

Table 1. Description of MPSA, SRL, and Questionnaire Response

\begin{tabular}{|c|c|c|c|c|c|c|c|}
\hline \multirow{2}{*}{ Variables } & \multirow{2}{*}{ Stat } & \multicolumn{3}{|c|}{$\begin{array}{l}\text { VBA Material Learning } \\
\qquad(\mathrm{n}=\mathbf{2 2})\end{array}$} & \multicolumn{3}{|c|}{$\begin{array}{l}\text { Ordinary Learning } \\
(\mathrm{n}=\mathbf{2 3})\end{array}$} \\
\hline & & Pretest & Postest & N-Gain & Pretest & Posttest & $\begin{array}{l}\mathrm{N}- \\
\text { Gain }\end{array}$ \\
\hline \multirow{3}{*}{ MPSA } & $\bar{X}$ & 3.45 & 63.05 & 0.69 & 4.30 & 50.91 & 0.54 \\
\hline & $\%$ & 3.84 & 70.05 & 69 & 4.78 & 56.57 & 54 \\
\hline & S & 2.50 & 12.33 & 0.14 & 3.35 & 14.72 & 0.17 \\
\hline \multirow{3}{*}{ SRL } & $\bar{X}$ & & 82.09 & & & 72.13 & \\
\hline & $\%$ & & 73.30 & & & 64.40 & \\
\hline & S & & 13.12 & & & 5.55 & \\
\hline \multirow{3}{*}{$\begin{array}{l}\text { Questionnaire } \\
\text { Response }\end{array}$} & $\overline{\bar{X}}$ & & 107.59 & & & 99.48 & \\
\hline & $\%$ & & 70.78 & & & 65.45 & \\
\hline & $S$ & & 12.14 & & & 12.19 & \\
\hline
\end{tabular}

Information: Ideal Score of MPSA $=90$

Ideal Score of SRL $=112$

Ideal Score of Questionnaire Responses $=152$

Table 1 show the MPSA pretest for the experimental class was $3.45(3.84 \%)$ lower than the control class value of $4.30(4.78 \%)$ where the two classes were at very low interpretation. Meanwhile, the posttest score of the experimental class was $78.18(69.81 \%)$ which was in the high interpretation, which was higher than the control class which was $50.91(56.57 \%)$ which was in sufficient interpretation. At the students' self-regulated 
learning given at the end of the meeting for the experimental class, it was $82.09(73.30 \%)$ which was in good interpretation, which was higher than the control class of $72.13(64.40 \%)$ in good interpretation too. In addition, the positive response of the experimental class students reached $107.59(70.78 \%)$ which was in a good interpretation, which was higher than the control class of 99.48 (65.46\%) who were in sufficient interpretation. On average and the percentage of learning outcomes in the experimental class is better than the control class.

Table 2. Testing hypothesis of mean difference of MPSA and SRL, and Questionnaire Response

\begin{tabular}{|c|c|c|c|c|c|c|c|}
\hline Variables & $\begin{array}{l}\text { Teaching } \\
\text { Method }\end{array}$ & Normality & Homogenity & $\mathbf{n}$ & $\begin{array}{c}\text { Sig } \\
\text { (2-tailed) }\end{array}$ & $\begin{array}{c}\text { Sig } \\
\text { (1-tailed) }\end{array}$ & Interpretation \\
\hline \multirow{2}{*}{ MPSA Pretes } & VBA & 0.007 & & 22 & \multirow{2}{*}{0.356} & & \multirow{2}{*}{$\begin{array}{c}\text { Pre-MPSAVBA } \\
= \\
\text { Pre-MPSA }_{\mathrm{OL}}\end{array}$} \\
\hline & $\mathrm{OL}$ & 0.017 & & 23 & & & \\
\hline \multirow{2}{*}{ MPSA Postes } & VBA & $0.200^{*}$ & \multirow{2}{*}{0.539} & 22 & \multirow{2}{*}{0.005} & \multirow{2}{*}{0.002} & Pos-MPSA \\
\hline & $\mathrm{OL}$ & $0.200^{*}$ & & 23 & & & Pos-MPSA $A_{\mathrm{OL}}$ \\
\hline \multirow{2}{*}{$\begin{array}{l}\text { N-Gain } \\
\text { MPSA }\end{array}$} & VBA & $0.200^{*}$ & \multirow{2}{*}{0.555} & 22 & \multirow{2}{*}{0.004} & \multirow[t]{2}{*}{0.002} & $\underset{>}{\mathrm{N}-\text { Gain }} \mathrm{MPSA}_{\mathrm{vBA}}$ \\
\hline & $\mathrm{OL}$ & $0.200^{*}$ & & 23 & & & N-Gain MPSA ${ }_{\mathrm{OL}}$ \\
\hline \multirow{2}{*}{ SRL } & VBA & $0.200^{*}$ & \multirow{2}{*}{0.000} & 22 & \multirow{2}{*}{0.002} & \multirow{2}{*}{0.018} & \multirow{2}{*}{$\begin{array}{c}\text { SRLVBA }_{\text {VI }} \\
>\mathrm{SRL}_{\mathrm{OL}}\end{array}$} \\
\hline & $\mathrm{OL}$ & 0.064 & & 23 & & & \\
\hline \multirow{2}{*}{$\begin{array}{l}\text { Questionnaire } \\
\text { Response }\end{array}$} & VBA & $0.200^{*}$ & \multirow{2}{*}{0.373} & 22 & \multirow{2}{*}{0.031} & \multirow{2}{*}{0.015} & \multirow{2}{*}{$\begin{array}{l}\text { Response vBA } \\
>\text { Response OL }\end{array}$} \\
\hline & $\mathrm{OL}$ & 0.101 & & 23 & & & \\
\hline
\end{tabular}

To answer the research hypothesis, a statistical test was carried out to see its significance. The results of the MPSA pretest show that there is no difference in the initial ability of solving mathematical problems between the experimental class and the control class (Table 2). After receiving the learning with teaching materials that have been determine the statistical test data shows that the post-test MPSA students experiment is significantly better than the control class. The n-gain data shows that the increase in the experimental class is significantly better than the control class students. On the SRL data shows that the experimental class students' SRL is significantly better than the control class students. And the positive response data shows that the positive response of the experimental class students is significantly better than the control class. This shows the successful use of VBA for Microsoft Word-based teaching materials in the implementation of learning in the new normal.

Table 3. Testing hypothesis of association betweet MPSA, SRL, and Questionnaire Response

\begin{tabular}{cccc}
\hline Variable & Sig (2-tailed). & Interpretation & $\mathbf{Q}$ \\
\hline MPSA and SRL & 0.000 & There is an Association & $\begin{array}{c}0.87 \\
(\text { High })\end{array}$ \\
\hline MPSA and Response & 0.053 & No Association & - \\
\hline SRL and Response & 0.075 & No Association & - \\
\hline
\end{tabular}

Based on Table 3, there is an association between MPSA and SRL students whose learning uses VBA for Microsoft Word based teaching materials with a high degree of 
association. However, there is no association between the positive responses of students and the results of student MPSA and SRL.

\subsection{Discussion}

VBA Microsoft Word-based teaching materials has a good impact in learning, shown by the very low initial ability of students to solve mathematical problems. After receiving learning, achievement and improved student MPSA is at a high level and better by significantly compared with students who receive other learning. It because nature of teaching materials based VBA Microsoft Word can be adjusted to the desired content and themes where the content of teaching materials can be customized by the indicators of the MPSA itself. The teaching material guides and requires students to recognize the difference between prisms and pyramids, then there are learning media that can be used to find concepts in the form of proving volume, surface area, nets by conducting experiments. Besides, sharpening students 'numeracy skills which is an obstacle causing students to incorrectly solve questions because students' number operations are still lacking, therefore in teaching materials there are counting operation tools. This is in line with research conducted by Bernard, Sumarna, Rolina, \& Akbar (2019) which shows that learning based on VBA Microsoft Word enables students to easily understand learning. In addition, other research also reveals that ICT-based learning can improve mathematical problem-solving abilities better than using ordinary learning (Darari, 2017; Puadi \& Habibie, 2018).

Furthermore, to analyzing the overall student MPSA test results, the students' errors in solving MPSA questions (see Figure 7).
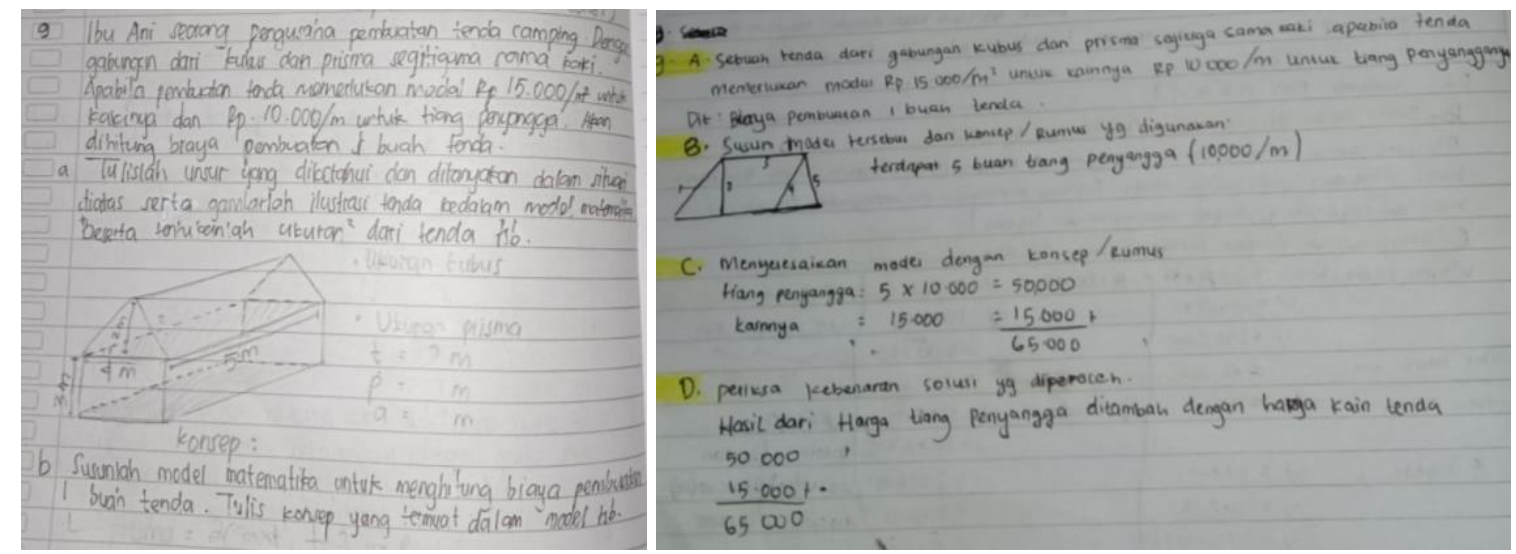

Figure 7. The mistakes of students in solving the MPSA questions

Figure 7 show the students mostly made mistakes in the calculation process, made mathematical models, and checked their answers again. This is because students do not have good mathematical problem-solving skills. Mathematical problem-solving abilities, namely the ability of students to understand problems, develop solving strategies, carry out strategies in solving problems, and finally students can re-examine the results of their work (Harisman et al., 2020; Hutajulu et al., 2019; Kusmaryono et al., 2018; Maharani et al., 2019; Maulidia et al., 2019).

In addition to students' cognitive abilities that need to be improved, students' affective abilities also need to be optimized, especially students' self-regulated learning abilities because they are closely related to learning at home during the new normal period. Using teaching materials based on VBA Microsoft Word, the achievement of student SRL is at a good level which is significantly better than students who receive regular learning. The 
results of giving the self-regulated learning scale are analyzed per indicator shown in Table 4.

Table 4. Achievement of students' self-regulated learning

\begin{tabular}{|c|c|c|}
\hline \multirow{2}{*}{ Indicator } & \multicolumn{2}{|c|}{ Percentage (\%) } \\
\hline & Experiment & Control \\
\hline Take the initiative to learn with or without the help of others & $75.81 \%$ & $66.15 \%$ \\
\hline Be able to overcome obstacles or problems & $72.24 \%$ & $62.42 \%$ \\
\hline Have Self-Confidence & $70.29 \%$ & $67.55 \%$ \\
\hline Doing something without the help of others & $74.84 \%$ & $61.49 \%$ \\
\hline Total & $73.30 \%$ & $64.40 \%$ \\
\hline
\end{tabular}

Table 4 show the attainment of independence on indicators of student learning initiative to learn with or without the help of others in the class experiment reached $75.81 \%$ and the control class is $66.15 \%$. The indicators of being able to overcome obstacles or problems in the experimental class reached $72.24 \%$ and the control class was $62.42 \%$. The indicators have self-confidence in the experimental class reaching $70.29 \%$ and the control class at $67.55 \%$. The indicators of doing something without the help of others in the experimental class reached $74.84 \%$ and the control class was $61.49 \%$. Overall the SRL of students in the experimental class reached $73.30 \%$ and the control class was $64.40 \%$. This shows that online learning using VBA Microsoft Word-based teaching materials makes students have better student SRL than students who receive regular learning in interpretation. good. This is in line with research conducted by Hendikawati, Zahid, \& Arifudin (2019) and Arifin \& Herman (2018) which reveal that learning using instructional media and/or ICTbased teaching materials has self-regulated learning better students.

Regarding student responses to learning, at the end of the meeting, students were given a response questionnaire according to each class's teaching. The student response analysis is presented in Table 5.

Table 5. Recapitulation of learning questionnaire results using VBA

\begin{tabular}{lcc}
\hline \multicolumn{1}{c}{ Statement Topic } & \multicolumn{2}{c}{ Percentage } \\
\cline { 2 - 3 } & Experiment & Control \\
\hline $\begin{array}{l}\text { Have an interest and enthusiasm in learning mathematics with the } \\
\text { teaching materials provided }\end{array}$ & 73.51 & 67.60 \\
$\begin{array}{l}\text { Able to overcome difficulties and dare to try new things } \\
\text { Able to understand the concept of learning through the teaching } \\
\text { materials provided }\end{array}$ & 70.35 & 66.60 \\
Able to interact online and have the courage to express opinions & 68.56 & 60.14 \\
\hline \multicolumn{1}{c}{ Total } & 65.68 & 62.39 \\
\hline
\end{tabular}

Table 5 show the attitudes and responses of students during learning were more positive even though learning was carried out online, whereas junior high school students were very active in their behavior. Students are more enthusiastic about learning at each meeting, and students can study independently at home according to the demands of learning in the new normal period. Some students even have already understood the material and completed each material content in VBA for Microsoft Word -based teaching materials. It 
can be concluded that learning using VBA Microsoft Word-based teaching materials can foster concept understanding, self-regulated learning, overcoming student difficulties in optimizing learning during the new normal period, besides that ICT-based learning makes students close to technology so that students will be ready to face the industrial revolution 4.0. This is in line with research conducted by Bernard et al. (2019) and Padli \& Rusdi (2020) which show that students respond positively to ICT-based learning, especially VBA Microsoft Word.

Based on the results of observations on the implementation of learning using teaching materials based on VBA Microsoft Word in terms of cognitive aspects, it can be seen that mastery of the concept of geometry of student shows perfect response and effect. This shows that the students can more quickly distinguish their characteristics and elements in the classification between prism and pyramid. Learning starts with formal mathematics, which then finds examples in everyday life that students, so they can distinguish and know the names of prisms and pyramids. Furthermore, the students' mathematical problem-solving ability is better. This can be seen in the evaluation stage during the learning process. Students can be providing solutions to the questions given. This is because VBA Microsoft Word has been prepared to have complete, structured, applicative content and follow the demands of MPSA itself.

The results showed that the mathematical problem solving abilities and self-regulated learning of students who studied using VBA Microsoft Word teaching materials were better than those who studied in the ordinary learning. This is show the VBA Microsoft Word teaching materials have several advantages, namely: (1) Microsoft Word is very close and familiar to teachers and students so that its use will not be difficult; (2) Learning in the new normal period becomes more effective because it can be used in various ways of learning face-to-face, offline and online and gives an interactive impression; (3) Can be manipulated according to the desired theme and content; (4) Can be made on other mathematical subjects; (5) Provide audio and visual stimuli and stimuli; (6) The content of teaching materials is in accordance with the daily lives of students so that learning will be more meaningful; (7) The costs required are relatively small or even unnecessary; (8) Everyday necessities that are accustomed to using Microsoft Word make it easy to access by users; (9) Students have become closer to ICT; (10) Learning during the new normal does not easily become bored for students; (11) ICT-based teaching materials are not easily damaged, easy to use, can be disseminated through various data sending media; (12) Shorter learning time; (13) Increasing the creativity of teachers in arranging teaching materials that can be adjusted under various conditions; (14) Easy to store, save storage memory; (15) The implementation of learning is more effective, efficient, systematic, and structured; and (16) The implementation of learning is centered on student contributions so that students are always ready and enthusiastic in learning.

\section{CONCLUSION}

The conclusions of this study are: (1) The results of using VBA Microsoft Wordbased teaching materials show that it is appropriate to apply in a new normal period, one of which is mathematics for junior high school students, especially in the most difficult material, namely wake polyhedron materials; (2) The achievement and improvement of students' mathematical problem-solving abilities who get learning with VBA Microsoft Word is better than those who get ordinary learning. The achievement and improvement of students' mathematical problem-solving abilities at a high level; (3) The students' selfregulated learning who get learning with VBA Microsoft Word is better than those who get ordinary learning. The students' self-regulated learning at a good level; (4) There is an 
association between MPSA and SRL, and no association betweet MPSA and SRL with student response levels; (5) Using VBA Microsoft Word-based teaching materials, students give a positive response amounting to $70.78 \%$; (6) Most of the student's difficulties in making a mathematical model in a matter of MPSA; and (7) Students more enthusiastic in learning and are not easily bored, in line with the challenges of the new normal period, revolutionary industrial 4.0, and the learning curriculum, learning is more structured, interactive, effective, and efficient.

\section{ACKNOWLEDGMENTS}

The author would like to thank the Director of the Directorate of Research and Community Service (DRPM BRIN) of the Republic of Indonesia and IKIP Siliwangi for research funding in 2020 with contract number 080/SP2H/AMD/LT/DRPM/2020, 144/SP2H/AMD/LT-MONO/LL4/2020, and 03/LPPM IKIP-Slw/KP-PT/V/2020.

\section{REFERENCES}

Adam, N. L., Alzahri, F. B., Soh, S. C., Bakar, N. A., \& Kamal, N. A. M. (2017). Selfregulated learning and online learning: a systematic review. International Visual Informatics Conference, 143-154). https://doi.org/10.1007/978-3-319-70010-6_14

Arifin, F., \& Herman, T. (2018). Pengaruh Pembelajaran E-Learning Model Web Centric Course Terhadap Pemahaman Konsep dan Kemandirian Belajar Matematika Siswa. Jurnal Pendidikan Matematika, 12(2), 1-12. https://doi.org/10.22342/jpm.12.2.4152.1-12

Bernard, M., Sumarna, A., Rolina, R., \& Akbar, P. (2019). Development of high school student work sheets using VBA for microsoft word trigonometry materials. Journal of Physics: Conference Series, 1315(1), 012031. https://doi.org/10.1088/17426596/1315/1/012031

Cárdenas-Robledo, L. A., \& Peña-Ayala, A. (2019). A holistic self-regulated learning model: A proposal and application in ubiquitous-learning. Expert Systems with Applications, 123, 299-314. https://doi.org/10.1016/j.eswa.2019.01.007

Darari, M. B. (2017). Penggunaan media adobe flash pada pembelajaran kesebangunan dalam meningkatkan kemampuan pemecahan masalah matematika siswa SMP negeri 7 Medan. JURNAL HANDAYANI PGSD FIP UNIMED, 7(2), 29-37. https://doi.org/10.24114/jh.v7i2.7233

Gabriel, F., Buckley, S., \& Barthakur, A. (2020). The impact of mathematics anxiety on selfregulated learning and mathematical literacy. Australian Journal of Education, 64(3), 227-242. https://doi.org/10.1177/0004944120947881

Guo, W., Lau, K. L., \& Wei, J. (2019). Teacher feedback and students' self-regulated learning in mathematics: A comparison between a high-achieving and a lowachieving secondary schools. Studies in Educational Evaluation, 63, 48-58. https://doi.org/10.1016/j.stueduc.2019.07.001

Guo, W., \& Wei, J. (2019). Teacher Feedback and Students' Self-regulated Learning in Mathematics: A Study of Chinese Secondary Students. The Asia-Pacific Education Researcher, 28(3), 265-275. https://doi.org/10.1007/s40299-019-00434-8 
Harisman, Y., Noto, M. S., \& Hidayat, W. (2020). Experience student background and their behavior in problem solving. Infinity Journal, 9(1), 59-68. https://doi.org/10.22460/infinity.v9i1.p59-68

Hendikawati, P., Zahid, M. Z., \& Arifudin, R. (2019). Keefektifitan Media Pembelajaran Berbasis Android terhadap Kemampuan Pemecahan Masalah dan Kemandirian Belajar. PRISMA, Prosiding Seminar Nasional Matematika, 2, 917-927.

Hendriana, H., Rohaeti, E. E., \& Hidayat, W. (2017). Metaphorical Thinking Learning and Junior High School Teachers' Mathematical Questioning Ability. Journal on Mathematics Education, 8(1), 55-64. https://doi.org/10.22342/jme.8.1.3614.55-64

Hutajulu, M., Wijaya, T. T., \& Hidayat, W. (2019). The effect of mathematical disposition and learning motivation on problem solving: an analysis. Infinity Journal, 8(2), 229238. https://doi.org/10.22460/infinity.v8i2.p229-238

Kamal, S. (2015). Implementasi pendekatan scientific untuk meningkatkan kemandirian belajar matematika. Math Didactic: Jurnal Pendidikan Matematika, 1(1), 56-64. https://doi.org/10.33654/math.v1i1.95

Krisnawati, R., Rohaeti, E. E., \& Maya, R. (2018). Application of a realistic approach to improve the ability of mathematical problem solving and self regulated learning of junior high school students. (JIML) Journal of Innovative Mathematics Learning, 1(2), 85-91. https://doi.org/10.22460/jiml.v1i2.p179-185

Kusmaryono, I., Suyitno, H., Dwijanto, D., \& Dwidayati, N. (2018). Analysis of abstract reasoning from grade 8 students in mathematical problem solving with SOLO taxonomy guide. Infinity Journal, 7(2), 69-82. https://doi.org/10.22460/infinity.v7i2.p69-82

Latifah, U. H., \& Widjajanti, D. B. (2017). Pengembangan bahan ajar statistika dan peluang berbasis multiple intelligences berorientasi pada prestasi, pemecahan masalah, dan rasa ingin tahu. Jurnal Riset Pendidikan Matematika, 4(2), 176-185. https://doi.org/10.21831/jrpm.v4i2.13083

Losenno, K. M., Muis, K. R., Munzar, B., Denton, C. A., \& Perry, N. E. (2020). The Dynamic Roles of Cognitive Reappraisal and Self-Regulated Learning During Mathematics Problem Solving: A Mixed Methods Investigation. Contemporary $\begin{array}{llll}\text { Educational Psychology, } & 101869 .\end{array}$ https://doi.org/10.1016/j.cedpsych.2020.101869

Maharani, S., Kholid, M. N., Pradana, L. N., \& Nusantara, T. (2019). Problem solving in the context of computational thinking. Infinity Journal, 8(2), 109-116. https://doi.org/10.22460/infinity.v8i2.p109-116

Maulidia, F., Johar, R., \& Andariah, A. (2019). A case study of students' creativity in solving mathematical problems through problem based learning. Infinity Journal, 8(1), 1-10. https://doi.org/10.22460/infinity.v8i1.p1-10

Padli, F., \& Rusdi, R. (2020). Respon siswa dalam pembelajaran online selama pandemi. Social Landscape Journal, 1(3), 1-7.

Peters-Burton, E. E., Cleary, T. J., \& Kitsantas, A. (2018). Computational thinking in the context of science and engineering practices: A self-regulated learning approach. Digital Technologies: Sustainable Innovations for Improving Teaching and Learning, 223-240. https://doi.org/10.1007/978-3-319-73417-0_13 
Puadi, E. F. W., \& Habibie, M. I. (2018). Implementasi PBL berbantuan GSP software terhadap peningkatan kemampuan pemecahan masalah matematik siswa. Indomath, Indonesia Mathematics Education Journal, 1(1), 19-26. https://doi.org/10.30738/indomath.v1i1.2091

Putra, H. D., Thahiram, N. F., Ganiati, M., \& Nuryana, D. (2018). Kemampuan pemecahan masalah matematis siswa SMP pada materi bangun ruang. JIPM (Jurnal Ilmiah Pendidikan Matematika), 6(2), 82-90. http://doi.org/10.25273/jipm.v6i2.2007

Rahmawati, A. Y., Rohaeti, E. E., \& Yuliani, A. (2018). Analisis kemampuan berpikir kritis matematis ditinjau dari kemandirian belajar siswa kelas xi melalui pendekatan metakognitif. JPMI (Jurnal Pembelajaran Matematika Inovatif), 1(4), 607-616. https://doi.org/10.22460/jpmi.v1i4.p607-616

Samo, D. D. (2016). An analysis of self-regulated learning on mathematics education student fkip Undana. Infinity Journal, 5(2), 67-74. https://doi.org/10.22460/infinity.v5i2.p67-74

Wahyudi, W., Ambarwati, M., \& Indarini, E. (2019). Development Of Web Game Learning Materials For Primary School Students. Infinity Journal, 8(2), 199-208. https://doi.org/10.22460/infinity.v8i2.p199-208 
